\title{
Problem Teaching: How to Plan for it
}

\section{Ruby Minor}

To cite this article: Ruby Minor (1920) Problem Teaching: How to Plan for it, Journal of Geography, 19:2, 61-69, DOI: 10.1080/00221342008984853

To link to this article: http://dx.doi.org/10.1080/00221342008984853

曲 Published online: 22 Feb 2008.

Submit your article to this journal $\pi$

Џ Article views: 2

Q View related articles $₫$ 
By treaty between the Allied and Associated Powers and Norway, Spitsbergen is to pass under Norwegian sovereignty. But the treaty provides some definite restrictions which place the islands in a special category. There is to be no naval base on any of the islands in the Spitsbergen group, and no use is to be made of Spitsbergen in time of war. All the signatories to the treaty are to enjoy fishing and hunting privileges in the territorial waters. Wireless stations are to be at the service of all, and an international meteorological station may be organized. Denmark is to represent the interests of Russia until that country gets on its feet again, and a Danish commissioner will examine all claims outstanding against the islands in one form or another. Final settlement of these claims is to be made by a tribunal of the interested powers with the Danish commissioner as president.

\section{PROBLEM TEACHING: HOW TO PLAN FOR IT By RUBY MINOR \\ State Normal College, Emporia, Kans.}

In almost every discussion of project teaching the question which seems to cause most concern is how to build the situation so that pupils will really feel the need of raising certain specific problems and will consciously purpose to answer these problems.

Intellectual Problems in the Elementaky Grades

A very prevalent attitude among educators is to believe that certain problems are too intellectual for elementary grade pupils. A common tendency is to consider that an attempt to include such material in the curriculum is an imposition of so much intellectual gymnastics upon the plastic mind of the pupil and is consequently to be avoided by the thoughtful guardian of the course of study.

That the imposition of intellectual problems unrelated to the child's interests is bad educational policy is admitted by all thoughtful advocates of project teaching; this admission, nevertheless, does not excuse the conscientious teacher from trying to lift his pupils to a higher plane of thinking. Otherwise the school 
becomes a mere market place for exchanging childish ideas without the educative leadership of a mature mind.

In trying to get away from the old régime of autocratic dictation by the teacher of certain facts which must be "covered," we are in danger of swinging into an uncharted way where the capricious whims of childhood are allowed to develop unguided into a purposeless round of petty achievements. Such achievements are but hints of what children may accomplish when guided by a teacher who is not only in sympathy with the child's interests but can also intelligently lead him to choose new and broader interests.

\section{Need of Careful Planning}

To formulate any set rules would defeat the purpose of the project-problem method. The absence of mechanical devices does not, however, preclude careful planning. In just what this planning shall consist seems to be the question which causes the greatest difficulty. Some seem to think that project-problem teaching can have no detailed planning by the teacher because the children are supposed to do the planning. But a teacher cannot expect to be successful without planning any more than can a general who hopes to lead his forces to victory. Analogies are often misleading; but, for the purpose of illustration, let us carry this analogy further. The efficient general must have a definite goal, he must know his men-their strength and weakness, he must be prepared for the unexpected emergency, he must know the field wherein he is to work, he must know when to take decisive action and when to lie in wait. Fortunately for the general he has reports from a wide field of others' experience to assist him; but, even so, these are but suggestions to help him in his preparations in the making of tentative plans. The final decisions, the particular plans, must be his own. He must often depend upon his own resourcefulness to bring order out of chaos and turn defeat into victory. How sad is the failure, and how great the cost of inefficiency may be readily seen in the history of any war.

In the annals of educational progress there can be traced failures just as ignominious, with results just as disastrous to the mental life of the nation as military inefficiency has proved to be to its physical life. The danger of inefficient, unprepared teach- 
ing is more insidious because the evil results are often not so tangible.

\section{An Illustation from Experience}

It is with the hope of giving a suggestion as to the kind of planning that is possible that the following experience is related. In an article (Project Teaching in Grade Six) in the Elementary School Journal for October, 1919, the writer described a project which motivated the work of nearly all of the school subjects in Grade VI for a semester. The work in geography was the centralizing force which led to the preparation of an Oriental exhibit. All work had as a general incentive this interesting goal.

For the purpose of illustrating just how the various problems might be launched let us consider the concrete case of the study of Japan. The teacher felt that she must not approach the study of Japan without knowing the country in a more detailed way than she had known it before especially in relation to current events. Further she had to consider the angle from which these particular pupils were best able to approach the study and thus she had to take stock of their fund of knowledge and of their ability. Her summary was somewhat as follows: This class had been much interested in the Great War. They knew the countries of Enrope in relation to the war. They were familiar with the problem method and had approached the study of Asia with one great question in mind, Why do we hear so much about Europe and so little about Asia? They had studied the countries of the Near East, raising those questions which are always of interest to children, for example, How do the people dress? What kind of homes have they?

After much consideration the following problem was selected as within the pupils' comprehension: Why is Japan the only Asiatic country that is considered a World Power?

Already the reader is probably mentally registering the objection that this is not a child's problem. But why should it not be a problem in Grade VI where pupils are constantly hearing world issues discussed, when there is scarcely a newspaper but has an item concerning Japan? (This class had one period a week in which newspaper elippings were read and discussed.) A few of these 
pupils would soon leave school, launched in the world as citizens, expected to know at least how to form opinions concerning issues of public interest.

Few Grade VI pupils, it is true, would select this problem of their own accord unless their interest were aroused. Here, then, was the next step for the teacher. It may be more interesting at this stage to give detailed procedure in order to show just how the pupils responded.

\section{'The Pupils' Response to the Problem}

Teacher: In our study of Europe into what groups did we usually classify the different countries?

Catherine: We usually spoke of them as Allies, Central Powers, and Neutrals.

Teacher: What is meant when a country is spoken of as a "Power"?

Frank: It means that is has power or influence with others countries.

Gertrude: It means that it is a leader among the nations.

Teacher: What countries of Asia have we studied? Locate them on the map as you name them.

William: Armenia, Palestine, Turkey, Arabia, and Persia.

Teacher: From what you know of these countries what do you think of them as World Powers?

Charles: They are not very important.

Anna Mae: They don't rank with European countries in power.

William: They have so much poverty and are so unprogressive that they have very little power.

Teacher: Which of the countries of Asia do you suppose may be a World Power?

Zelda: I think perhaps China might be.

Teacher: Why?

Zelda: It is the largest country on the map.

Teacher: Does her answer sound reasonable?

Edward: Size might help, but I think Japan is just as important as China. Teacher: I have a few magazines here with very interesting articles. They are a little difficult for you to understand, but they each have a paragraph which will help us at this time. (Teacher reads brief paragraphs from the Outlook, the Independent, etc., which tell of two important Japanese commissions in this country.) Why do you suppose so many of our leading magazines are printing articles concerning Japan and her relations with the United States?

Dorothy: Japan must be a very important country. 
Teacher: Last year when I was in New York I walked over to Riverside Park one day for my usual exercise and was surprised to see an immense crowd around Grant's Tomb. The tomb was beautifully decorated, policemen were hastening about, and everyone was excited. Suddenly a procession of automobiles brought several Japanese gentlemen to visit the tomb. The Mayor of New York escorted these men, and thousands of our soldiers paraded past the tomb for their inspection. Why do you suppose so much attention was given to these particular men?

Harris: They must have been sent by the Japanese government.

Teacher: They were the men who are mentioned in these magazine articles. But, here, in our own book, "Japan," from the series "Peeps at Many Lands," is a paragraph which gives us the best idea of all: "The rise of Japan in becoming one of the great Powers of the world has been very sudden and wonderful." What problem does all of this discussion raise in your mind?

Charles: Why is Japan so important?

Teacher: Would anyone word it differently?

William: Why is Japan the most important World Power in Asia?

Teacher: Does anyone want to include another idea in the wording of the problem?

Frank: Why is Japan the only country in Asia that is considered a World Power?

Teacher: Whose wording of the problem do you think is best? Then let us put Frank's problem on the board, so that we can have it to guide us in our thinking. Let us read it together. What do you think we need to know in order to solve this problem?

Will: I think we should know the size of Japan. (Teacher placed topics on board as pupils suggested them.)

Teacher: Why do you think that will help?

Will: The size of any country usually has something to do with its importance.

Frances: We ought to know something about its climate, because that has so much to do with its products.

Earl: I think we shall want to know something about the people.

Emile: We want to know the resources of Japan.

Teacher: I'm glad Emile thought of that. It shows that he remembers a new word in our vocabulary. Of what importance is that topic in our study?

Charles: A country's resources have something to do with its wealth and commerce. 
Frank: Don't you think we ought to study about Japan's commerce?

Teacher: What do you think, class?

Milton: I think commerce is a very important topic, because it shows what countries Japan trades with.

Teacher: We have a number of good suggestions now. In what order do you think we should study these topies? I shall number them as you wish.

Constance: Size should come first.

Teacher: If you were going to visit this country, what would you want to know first?

Frank: I should want to know in what direction to sail, and just where Japan is located.

Teacher: How many would consider location the best topic to study first? Then we shall number that I. Just what are you interested in about the location?

Norman: How far it is from the United States?

William: In what direction and how far it is from the countries of Europe. Teacher: Why do you think its relation to these countries is important?

William: The United States is the most important World Power just now, and Japan's trade depends upon reaching the United States or Europe.

Teacher: Just what do you care to know about the distance?

Catherine: How many miles it is to Japan.

Frances: How many days it takes to make the voyage.

Teacher: Which is really the more interesting? Then we shall put "distance in days"' in our outline. What topic is next?

Beulah: I think it doesn't matter much which comes next, but size might come after location.

Teacher: What subtopics do you wish to remember?

Miriam: Population and area.

Teacher: Read the problem again. Let's be sure that we know why we are planning all of this work. Why do you think that knowing population and area might help to solve our problem?

Miriam: The number of people in a country has something to do with its importance, and the area tells how much land they have.

Teacher: Are there any other topies here that you care to discuss before we begin to study?

Edith: Under climate I think we might have-subtopies temperature and rainfall.

Milton: I know a big topic that we've omitted-surface.

Teacher: Why is that important?

Milton: If they have mountains, they may have mines, or if they have valleys they may have large farms.

Teacher: And that brings us to the most interesting topic of all. What is it?

Edith: The people. 
Teacher: Now let's have several subtopies suggesting the problem about the people in which you are most interested.

\section{The Completed Outuine}

This lesson closed in one half hour with the following outline completed ready for study and a few brief suggestions by members of the class as to how to study, where to find material, how to use it, ete.

I. Location

A. Direction, and distance in days from

1. United States

2. European countries

3. Asiatic countries

II. Size

A. Population

1. Compared with the United States

2. Compared with the countries of Europe and Asia

B. Area

1. Compared with the United States

2. Compared with the European countries

3. Compared with the Asiatic countries

III. Climate

A. Temperature (compared)

B. Rainfall (compared)

IV. Resources

V. Surface
A. Mountains
B. Rivers

1. Drainage

VI. People

A. Appearance

1. Race

2. Dress

B. Industries and Occupations

C. Homes

D. Schools

E. Character.

Method of Solution

Each day a part of the class period was given to supervised study in order that the teacher might be able to assist pupils in acquiring economical habits of study. Pupils were encouraged to 
read their textbooks, then to consult other references which were conveniently placed for their use. (See bibliography.)

Often the literature period was used in reading delightful stories and poems of Japan. Lantern lectures and stereograph views added interest to the study of many topies. Frequently a summary was made, and a checking-up scheme was used to see what topics in our outline were not yet reported on. Sometimes we tried to answer our problem but always with the idea in mind that more study might change our opinion. As each topic was approached the pupils worded a minor problem the solution of which was a goal toward which to work and a criterion by which to evaluate all material. As these minor problems were answered the way was cleared for a better understanding of the main problem.

The above plan is only one of many ways in which a problem may be suggested and the class started to work. It is very important that the problem be kept in mind, especially when summarizing, in order that there may be unity and purpose in the or. ganization of facts.

It is equally desirable that other questions may arise and other lines of activity be suggested and continued, so that the pupils may gradually enlarge their experience and thus acquire knowledge, skill, and attitudes that will enable them to be intelligent participants in the life about them.

\section{References (Suitable for Children)} York.

John Finnemore: Japan. (Series: Peeps at Many Lands.) Macmillan Co., New

Ume' San in Japan. (Series: Little People Everywhere.) Little, Brown \& Co., Boston.

L. M. Chance: Little Folks of Many Lands. Ginn \& Co., Boston.

F. G. Carpenter: Around the World with the Children. American Book Co., New York.

F. G. Carpenter: Asia. (Carpenter's Geographical Readers.) American Book Co., New York.

N. B. Allen: Geographical and Industrial Studies; Asia. Ginn \& Co., Boston.

Ellsworth Huntington: Asia: A Geography Reader. Rand MeNally Co., Chicago.

Harriet Miller: Little People of Asia. E. P. Dutton \& Co., New York.

Mary Cate Smith: Life in Asia. Silver, Burdett \& Co., New York.

Mrs. M. (Chaplin) Ayrton: Child Life in Japan. D. C. Heath \& Co., Boston.

Marian M. George: China and Japan. (Little Journeys.) A. Flannigan Co, Chicago.

H. Clive Barnard: Asia in Pictures. A. \& C. Black, London.

Luey F. Perkins: The Japanese Twins. Houghton, Mifflin Co., Boston.

Mary H. Wade: Our Little Japanese Cousin. C. Page and Co., Boston. 
Mae St. J. Bramball: Wee Ones of Japan. Harper \& Bros., New York.

T. W. Knox: Japan and China. (Boy Trasellers.) llarper \& Bros., Nen York.

Teresa P. Williston: Japanese Fairy Tales. Rand-MeNally \& Co., Chicago.

Mary F. Nixon-Ronlet: Japanese Folk Stories and Fairy Tales. American Book Co., New York.

Mary (MeNeill) Fenollosa: Blossoms from a Japancse Garden. F. A. Stokes Co.. New York.

\section{THE NATIONAL COUNCIL OF GEOGRAPHY TEACHERS*}

By GEORGE J. MILLER

State Normal School, Mankato, Minn.

As many of you know the morement to organize the National Council of Geography Teachers was started in 1914, and the organization was completed the following year. Its purpose is to "increase the effectiveness of geography teaching in America (a) by promotion of national educational movements; (b) by cooperation in the organization and development of state councils; and (c) in such other ways as the officers may from time to time determine." It aims to accomplish its work through the study of educational problems and the contribution of its findings to the country as a whole; by giving its assistance to school officials, and by providing speakers for meetings. It is probable that the most effective immediate results will be accomplished by the cooperative efforts of state and local councils. The National Council should give the largest measure of assistance possible to the state organizations.

\section{Present Organization of State Councils}

When the National Council was organized there was in the United States but one state organization devoted to advancing the teaching of geography. State organizations now exist in twentyfive states and will probably be established in four others during 19:0. Leaders are at work in four other states but they do not consider that local conditions favor organization at present. Death has produced a vacancy in one state. This leaves fifteen states without leaders. These states are New Mexico, Nerada, Wyo-

\footnotetext{
*A report presented at the St. Louis meeting of the Council by the Secretary.
} 